УДК 316.35

$10.17213 / 2075-2067-2020-5-112-117$

\title{
МОЛОДЕЖНОЕ ВОЛОНТЕРСТВО В УСЛОВИЯХ ПАНДЕМИИ
}

\author{
(C) 2020 г. В. В. Овсий
}

\section{Южный федеральный университет, г. Ростов-на-Дону, Россия}

Целью исследования является анализ реализачии добровольческих молодежных проектов в России, их активность и значение в современном обществе, а также практическая деятельность в условиях пандемии.

Методологическая база исследования строится на концепџии институциионального подхода (Д. Норта). В рамках этого подхода волонтерство рассматривается как социальный институт, особый институт гражданского общества, основу функционирования которого составляет принции иелостности и солидарности.

Результаты исследования. Важнейтим результатом явилось понимание усилившейся активности молодежного волонтерского движения в условиях новой реальности. Наблюдается эффект «взросления общества», его переход к активным действиям взамен повсеместно царившей ранее пассивности и безучастности к происходящему. У молодых людей виден рост таких качеств, как осознанность своих действий, сострадание к ближнему, стойкость в тяжельх жизненных ситуациях.

Перспективу исследования составляет углубленный анализ волонтерских практик, позволяющий органам власти координировать соответствующим образом государственную молодежную политику.

Ключевые слова: молодежное волонтерство; студенчество; добровольчество; пандемия.

\section{YOUTH VOLUNTEERING IN THE CONTEXT OF THE PANDEMIC}

\section{(C) $2020 \quad$ V. V. Ovsii}

\section{Southern Federal University, Rostov-on-Don, Russia}

The purpose of the study is to analyze the implementation of voluntary youth projects in Russia, their activity and significance in modern society, as well as their activities in the context of a pandemic.

The methodological base of the study is based on the concept of the institutional approach (D. North). In this approach, volunteerism is considered as a social institution, a special institution of civil society, which is based on the principle of integrity and solidarity.

The results of the study. The most important result was an understanding of the increased activity of the youth volunteer movement in the new reality. There is an effect of "growing up of society", its transition to active actions, instead of the passivity and indifference to what is happening that prevailed everywhere before. Young people show an increase in such qualities as awareness of their actions, compassion for others, and resilience in difficult life situations.

The prospect of the study is an in-depth analysis of volunteer practices that will allow authorities to coordinate state youth policy accordingly.

Key words: youth volunteering; students; volunteerism; pandemic. 
Введение. В российском обществе в последние пять лет наметилась устойчивая тенденция существенного разрыва потенциального и реального уровня участия в волонтерских и добровольческих проектах (50\% против 15\%) [3]. Данная тенденция требует активизации деятельности, направленной на вовлечение в волонтерское движение новых участников, что приобрело особую актуальность в условиях пандемии, с которой столкнулось мировое сообщество. Одним из ответов в борьбе с пандемией стало активное участие молодежного волонтерства в оказании помощи нуждающимся гражданам нашей страны.

Глобальный вызов для волонтерства: роль и значение в современном обществе. Волонтерская деятельность представляет для молодежи эффективный механизм выстраивания социальных отношений и взаимодействий, служит базой приобретения новых знаний, умений и навыков, формирует и раскрывает собственный духовно-личностный потенциал [1]. Участие в волонтерских проектах и движении позволяет молодым людям эффективнее социализировать и коммуницировать в обществе, осваивать нормы и правила, что характеризует волонтерство как социальный институт, формирующий общественный капитал и создающий условия для продуктивного взаимодействия всех групп и общностей, что особенно актуально для молодого поколения как отдельной социально-демографической группы.

Социологические исследования показывают, что наибольшую вовлеченность в волонтерское движение проявляют именно молодые люди: так, по данным ВЦИОМ, 22\% граждан нашей страны в возрасте от 18 до 24 лет безвозмездно оказывали помощь [3], «Левада-Центр» в своих исследованиях утверждает, что именно 18-25-летние являются активными волонтерами. Средний возраст добровольца составляет 23 года [2]. По данным «Росмолодежи», в волонтерской деятельности приняли участие 4101170 молодых людей в возрасте от 14 до 30 лет, что составляет $15 \%$ от данной возрастной группы $[5,6]$.

Мощным толчком для развития волонтерского движения в России послужили зимние Олимпийские Игры в Сочи. За послед- ние пять лет количество волонтеров в нашей стране выросло в три раза. Доля волонтеров от общей численности россиян составляет $15 \%$ (по сравнению с 2004 г. - 5\%), это порядка 15 миллионов человек, большую часть из которых составляют студенты либо молодые люди, недавно окончившие учебные заведения [12].

Молодежное волонтерство в период пандемии. Одним из наиболее популярных направлений волонтерства в нашей стране является «эпизодическое волонтерство», т.е. принятие разового участия в событиях, выполнение четких, несложных поручений. По данным центра исследований гражданского общества и некоммерческого сектора НИУ ВШЭ, в эпизодическом волонтерстве предпочитают участвовать жители городовмиллионников. Примерно четверть от общего числа опрошенных составляют студенты $26 \%$ [9]. Однако в тяжелый период пандемии сотни студентов пополнили ряды волонтеров в России и стали работать отнюдь не по эпизодическому принципу. Их деятельность включает в себя несколько направлений: это адресная помощь маломобильным слоям населения, помощь медицинскому персоналу в больницах, информирование населения, работа в колл-центрах.

Большинство волонтерских центров вузов страны присоединились к акции \#мывместе с целью проведения общих офлайн-мероприятий, координации действий на уровне региона, а также с целью обеспечения безопасности студентов-волонтеров. Несомненно, студенты-медики особо востребованы в качестве волонтёров, они помогают медицинским работникам справиться с колоссальной нагрузкой, при этом помощь студентов других направлений подготовки также необходима населению в сложившейся ситуации. Так, к примеру, особо востребованы волонтеры-студенты, обучающееся по направлению «социальная работа», «педагогика», «психология» в сложившейся ситуации.

Молодежное волонтерство в условиях пандемии включает не только вертикальные практики, но и горизонтальные - взаимопомощь среди студентов. Так, например, студенты-волонтеры МИФИ организовали помощь студентам, которые на время пандемии 
вынуждены остаться в общежитиях, организована помощь иностранным студентам, которые из-за закрытия границ не могут уехать домой [9].

Особое направление в волонтерстве приобрело «цифровое» или «ІТ-волонтерство» в связи с тем, что все образовательные учреждения были вынуждены уйти в дистанционный формат в кратчайшие сроки, многим педагогам понадобилась помощь в освоении нового софта. Студенты-волонтеры Томского государственного университета систем управления и радиотехники помогают образовательным учреждениям решать различного рода технические проблемы, устанавливать и осваивать новые программные продукты [9].

Студенты Южного федерального университета создали цифровую модель распространения новой коронавирусной инфекции (COVID-19) на основе актуальных данных отечественных и зарубежных платформ, благодаря чему появился полноценный доступ к множеству датасетов, формируемых различными организациями от Роспотребнадзора до англоязычных ресурсов (Kaggle, Demension). Данные стекаются в режиме онлайн и позволяют наиболее точно оценить ситуацию, спрогнозировать тенденции и выработать соответствующие решения [10].

Особая значимость волонтерского движения отмечена и на государственном уровне. Так, Президент Российской Федерации на встрече с добровольцами дал высокую оценку волонтерству в условиях пандемии, отметив, что такая работа, безусловно, востребована и будет приветствоваться и поддерживаться. Владимир Путин подчеркнул, что необходимо позаботиться о тех, кто проводит соответствующие мероприятия, позаботиться об их безопасности, их собственном здоровье. В качестве поддержки молодежного волонтерства в Российской Федерации собираются в два раза повысить стипендии для студентов, помогающих медикам в борьбе с пандемией коронавируса [4]. При этом студенты вступают в ряды волонтеров отнюдь не за материальными благами и всеобщим признанием, а по зову сердца, чтобы приносить пользу людям в сложные времена.

Современные вызовы мирового масштаба выступили своеобразным драйвером гражданских инициатив и студенческого волон- терского движения в России. Исследователи отмечают, что при положительной тенденции роста числа заболевших растет и число молодых людей, желающих стать волонтерами. Так, к вузовской волонтерской акции \#мывместе за время пандемии в России приняло участие более 107 тысяч волонтеров [8].

Особенностью деятельности студентов-волонтеров в период пандемии является учет их направления подготовки, при этом студенты вносят не только вклад в борьбу с вирусом, но и развивают свои профессиональные и личностные навыки и качества. Так, А.Е. Чагин среди задач, решаемых с помощью волонтерской деятельности, рассматривает формирование и развитие знаний, умений и навыков, как следствие - развитие инновационного потенциала, а также формирование социального, культурного капитала и символического капитала [11].

Таким образом, с одной стороны, волонтерство, о чем явно свидетельствуют результаты исследований деятельности добровольцев, оказывает воздействие на граждан, формируя у них готовность к решению актуальных общественных проблем, благоприятствуя образованию в обществе так называемого «мобилизационного потенциала», базирующегося на готовности к активному социальному поведению именно в силу внутреннего убеждения, а не вследствие какого-либо принуждения [7]. С другой стороны, вследствие осуществления волонтерами своей деятельности происходит создание соответствующих сообществ, осуществляется расширение круга социальных связей, что, в свою очередь, способствует повышению уровня профессионализации субъектов волонтерской активности, появлению у них новых возможностей в плане построения успешной карьеры, удовлетворению потребностей в самореализации.

Выводы. Масштабная эпидемия, охватившая весь мир, показала много отрицательных моментов в жизни общества. Однако эта же проблема явилась и толчком к консолидации различных социальных институтов и движений взаимопомощи в обществе, усовершенствовании различных прикладных элементов в моменты стрессовых ситуаций и ограничений. 
Особенностью рассмотрения молодежного волонтерского движения в условиях пандемии стало активное включение молодых людей в работу по оказанию помощи населению, в которой они применяли свои профессиональные навыки, полученные в период обучения в вузе.

Непростая ситуация с эпидемиологической обстановкой выявила некую солидарность в образовательном процессе. В технических аспектах налаживания дистанционного обучения студенты проявили активность в помощи настройки программного обеспечения на различных онлайн-платформах и в освоении нового софта.

Кризис дал возможность проявить лучшие качества людей, лишний раз обратил внимание государства на волонтерское движение в нашей стране, обозначил интеллектуальную, временную и мобилизационную готовность населения и органов власти к решению поставленных задач, студентам-волонтерам предоставил возможность проявить себя как профессионалам. В результате проведенного исследования следует особо подчеркнуть, что в российском обществе наметилась тенденция осознания и ответственности за происходящее, граждане все чаще режиму пассивности предпочитают активные действия в разворачивающихся событиях, тратят на решение проблем общества свои силы и время.

\section{Литература}

1. Баланян М.Н. Социокультурный потенциал волонтерского движения современной студенческой молодежи: автореф. дис.... канд. социол. наук. - Майкоп, 2015. - 29 c.

2. Взаимопомощь во время пандемии. Склонны ли россияне друг другу помогать? И стали ли больше помогать в пандемию? [Электронный ресурс] Всероссийский опрос проведен Фондом общественного мнения 24 26 апреля $2020=1000$ респондентов. - Режим доступа: https://fom.ru/TSennosti/14393 (Дата обращения: 29.05.2020).

3. Волонтерство в России: сегодня и завтра. Пресс-выпуск ВЦИОМ от 03 апреля 2018 г. [Электронный ресурс] - Peжим доступа: https://wciom.ru/index. php?id=236\&uid=9020 (Дата обращения: 15.05.2020).

4. Встреча В. Путина с участниками общероссийской акции «Мы вместе» от 30 апреля 2020 г. [Электронный ресурс] — Peжим доступа: http:/www.kremlin.ru/events/ president/news/63294 (Дата обращения: 30.05.2020).

5. Добровольчество и волонтерство: как мы помогаем друг другу? ВЦИОМ. 2018. [Электронный ресурс] - Режим доступа: https://wciom.ru/index.php?id=236\&uid $=9380$ (Дата обращения: 18.05.2020).

6. Итоги федерального статистического наблюдения в сфере молодежной политики за 2019 г. [Электронный ресурс] — Режим доступа: https://fadm.gov.ru/activity/statistic (Дата обращения: 18.05.2020).

7. Киселев И.Ю. Волонтерство как социальный капитал // Вестник социальнополитических наук. Ярославский государственный университет им. П.Г. Демидова. 2013. — №12. - С. 60.

8. Потенциал гражданского участия в решении социальных проблем. Сводный аналитический отчет [Электронный peсурс] - Режим доступа: http://www.levada. $\mathrm{ru} / \mathrm{sites} /$ default/files/potencial_grazhdanskogo uchastiya_0.pdf(Дата обращения: 18.05.2020).

9. Скокова Ю., Краснопольская И., Корнеева И. Практика вузов в поддержке волонтерской деятельности студентов в период пандемии [Электронный ресурс]. САО-Экспрес №6 (в доработке) НИЦ ВШЭ. 2020. — Режим доступа: https://ioe.hse.ru/sao_volunteers (Дата обращения: 10.05.2020).

10. Ученые ЮФУ создают и анализируют датасеты о COVID-19 [Электронный ресурс] Пресс-центр ЮФУ от 02.04.2020 г. — Режим доступа: https://www.sfedu.ru/www2/web/ press-center/news/62583 (Дата обращения: 18.05.2020).

11. Чагин A.E. О роли волонтерской деятельности в студенческой среде [Электронный ресурс] // Молодой ученый. - 2015. №10 (90). — С. 1327-1329. - Режим доступа: https://moluch.ru/archive/90/19268/ (Дата обращения: 26.05.2020).

12. Число волонтеров в России утроилось за пять лет [Электронный ресурс] - Режим доступа: https://tass.ru/obschestvo/6529522 (Дата обращения: 18.05.2020). 


\section{References}

1. Balanjan M.N. Sociokul'turnyj potencial volonterskogo dvizhenija sovremennoj studencheskoj molodezhi: [Sociocultural potential of the volunteer movement of modern student youth: Ph. D. (Sociology) Thesis]. - Majkop, 2015. - 29 p.

2. Vzaimopomoshh' vo vremja pandemii. Sklonny li rossijane drug drugu pomogat'? I stali li bol'she pomogat' v pandemiju? [Mutual aid during a pandemic. Do Russians tend to help each other? And did they help more in the pandemic?] [Jelektronnyj resurs] Vserossijskij opros proveden Fondom obshhestvennogo mnenija 24-26 aprelja $2020=1000$ respondentov [The all-Russian survey was conducted by the public opinion Foundation on April 24-26, 2020 $=1000$ respondents]. — URL: https://fom.ru/TSennosti/14393 (Date accessed: 29.05.2020).

3. Volonterstvo v Rossii: segodnja i zavtra. Press-vypusk VCIOM ot 03 aprelja 2018 g. [Volunteering in Russia: today and tomorrow. VTSIOM press release from April 03, 2018] [Jelektronnyj resurs] - URL: https://wciom.ru/ index.php?id=236\&uid $=9020$ (Date accessed: 15.05.2020).

4. Vstrecha V. Putina s uchastnikami obshherossijskoj akcii «My vmeste» ot 30 aprelja 2020 g. [Vladimir Putin's Meeting with participants of the all-Russian action «We are together» on April 30, 2020] [Jelektronnyj resurs] URL: http://www.kremlin.ru/events/president/ news/63294 (Date accessed: 30.05.2020).

5. Dobrovol'chestvo i volonterstvo: kak my pomogaem drug drugu? [Volunteering and volunteering: how do we help each other?] VCIOM. 2018. [Jelektronnyj resurs] — URL: https://wciom.ru/index.php?id=236\&uid=9380 (Date accessed: 18.05.2020).

6. Itogi federal'nogo statisticheskogo nabljudenija v sfere molodezhnoj politiki za 2019 g. [Results of the Federal statistical observation in the field of youth policy for 2019] [Jelektron- nyj resurs] — URL: https://fadm.gov.ru/activity/ statistic (Date accessed: 18.05.2020).

7. Kiselev I. Ju. Volonterstvo kak social'nyj kapital [Volunteering as social capital] // Vestnik social'no-politicheskih nauk. Jaroslavskij gosudarstvennyj universitet im. P. G. Demidova [Bulletin of social and political Sciences. Yaroslavl State University named after P.G. Demidov]. - 2013. - №12. - P. 60.

8. Potencial grazhdanskogo uchastija v reshenii social'nyh problem. Svodnyj analiticheskij otchet [The potential of civil participation in solving social problems. Summary analytical report] [Jelektronnyj resurs] — URL: http://www. levada.ru/sites/default/files/potencial_grazhdanskogo_uchastiya_0.pdf (Date accessed: 18.05.2020).

9. Skokova Ju., Krasnopol'skaja I., Korneeva I. Praktika vuzov v podderzhke volonterskoj dejatel'nosti studentov v period pandemii [University Practice in supporting students' volunteer activities during the pandemic] [Jelektronnyj resurs]. SAO-Jekspres №6 (v dorabotke) NIC VShJe. 2020. — URL: https://ioe.hse.ru/sao_ volunteers (Date accessed: 10.05.2020).

10. Uchenye JuFU sozdajut i analizirujut datasety o COVID-19 [SFU Scientists create and analyze datasets about COVID-19] [Jelektronnyj resurs] Press-centr JuFU ot 02.04.2020 g. URL: https://www.sfedu.ru/www2/web/presscenter/news/62583 (Date accessed: 18.05.2020).

11. Chagin A.E. O roli volonterskoj dejatel'nosti v studencheskoj srede [On the role of volunteer activities in the student's environment] [Jelektronnyj resurs] // Molodoj uchenyj [Young scientist]. - 2015. — №10 (90). S. 1327-1329. - URL: https://moluch.ru/archive/90/19268/ (Date accessed: 26.05.2020).

12. Chislo volonterov v Rossii utroilos' za pjat' let [The number of volunteers in Russia has tripled in five years] [Jelektronnyj resurs] URL: https://tass.ru/obschestvo/6529522 (Date accessed: 18.05.2020). 


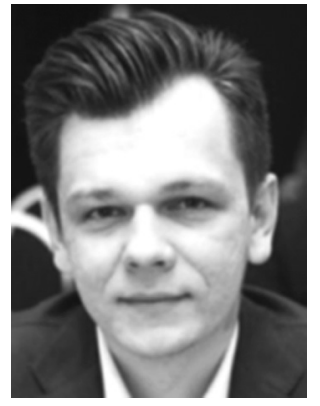

Овсий Виталий Вадимович - аспирант Института социологии и регионоведения Южного федерального университета. Сфера научных интересов - проблемы молодежного волонтерства.

Ovsii Vitaly Vadimovich - Post-graduate Student, Institute of Sociology and Regional Studies, Southern Federal University. Sphere of scientific interests - problems of youth volunteering.

344006, г. Ростов-на-Дону, ул. Пушкинская, 160

160 Pushkinskaya st., 344006, Rostov-on-Don, Russia

E-mail: v.ovsij@yandex.ru 